\title{
Ruthenium-Catalyzed Enantioselective Transfer Hydrogenation
}

Category

Metals in Synthesis

\section{Key words}

ruthenium catalysis

transfer

hydrogenation

alcohols

\section{Syníact $\dot{0}$}

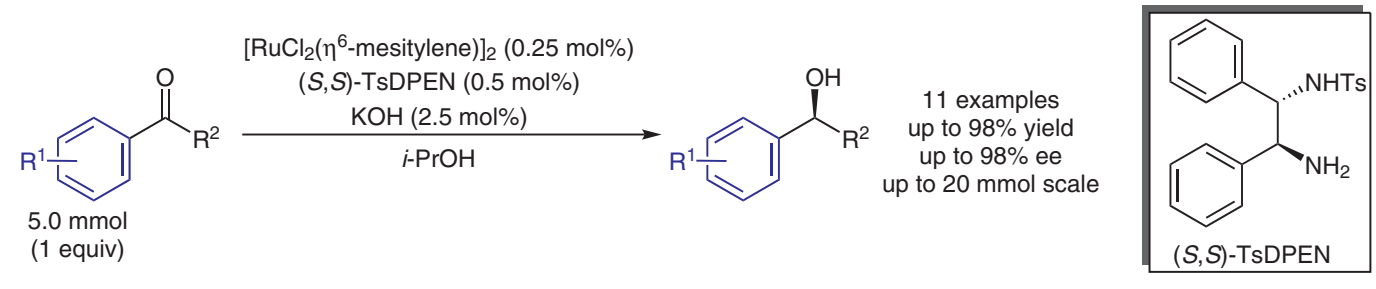

Selected examples:<smiles>CC(O)c1ccccc1</smiles>

$95 \%$ yield, $97 \%$ ee<smiles>OC1CCCc2ccccc21</smiles><smiles>CCC(O)c1ccc(Cl)cc1</smiles>

$94 \%$ yield, $97 \%$ ee<smiles>OC1CCc2ccccc21</smiles><smiles>CC(O)c1cccc(Cl)c1</smiles>

$98 \%$ yield, $98 \%$ ee<smiles>CC(O)c1ccc2ccccc2c1</smiles><smiles>COc1cccc(C(C)O)c1</smiles>

$96 \%$ yield, $96 \%$ ee<smiles>CC(O)c1cccc2ccccc12</smiles>

Scale-up:<smiles>CC(=O)c1cccc(Cl)c1</smiles>

$20 \mathrm{mmol}$
$\left[\mathrm{RuCl}_{2}\left(\eta^{6} \text {-mesitylene }\right)\right]_{2}(0.1 \mathrm{~mol} \%)$

$(S, S)$-TsDPEN $(0.4 \mathrm{~mol} \%)$ $\mathrm{KOH}(1.0 \mathrm{~mol} \%)$ $i-\mathrm{PrOH}$

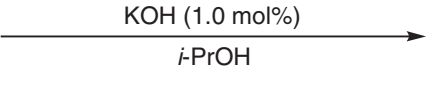<smiles>CC(O)c1cccc(Cl)c1</smiles>

$95 \%$ yield, $98 \%$ ee
Significance: The work reported by Noyori and co-workers regarding ruthenium-catalyzed asymmetric transfer hydrogenation, represented one of the first reports describing this process with high asymmetric induction and turnover number. This transformation offers advantages over traditional hydrogenation methods that employ hydrogen gas, such as i) avoidance of pressurized $\mathrm{H}_{2}$ gas, ii) inexpensive and synthetically convenient hydrogen sources, and iii) recyclable byproduct from the oxidation of the hydrogen surrogate (D. Wang, D. Astruc Chem. Rev. 2015, 115, 6621-6686).
Comment: Isopropanol was used as the solvent and serves as the hydrogen surrogate, generating acetone as a byproduct. The chiral alcohols were obtained in good to excellent yields, and excellent enantioselectivities. The scalability of this process was demonstrated by carrying out the reaction in a $20 \mathrm{mmol}$ scale, yielding the product without erosion of either enantioselectivity or yield. The authors note that extended reaction times and higher concentrations ( $1 \mathrm{M}$ as opposed to $0.1 \mathrm{M}$ ) result in the deterioration of enantioselectivity. 